18-20 December, 2020

Oxford, United Kingdom $11^{\text {th }}$ International Conference on

Humanities, Psychology \& Social Sciences

\title{
Remembering Greek Pontian Genocide using dance commemoration as a prosthetic memory tool
}

\author{
Anagnastopol Bogdan Eugen* \& Pachatouridis Omiros** \\ *Babes Bolyai University, Cluj-Napoca, Romania, ** Pyrichios Academy, Athens, Greece
}

\begin{abstract}
.
Memory studies and Mentalities history, in the form of nostalgia, is having the tendency to drag people and the audience into the past instead of present. One of the main philosophical concepts who stand for the form of nostalgia is to remember the actions did in the past in order to be avoided in the present or future. Prosthetic memory as part of Memory studies, can be used as a channel of communication for the cultural heritage and history events who are specific for an ethnic group, small community or a family, derive from personal memories, with the role to attach a lost part of imaginary population mental within either in the same community or to a different community. In this way, Prosthetic memory is refilling the memory gap occurred during the historical evolution, and it's a new modality to continue the cultural memory in an artistic form. The present study aims to present the direction and choreology representation of the Greek Pontian Genocide in form of Prosthetic memories within Greek Pontian ethnic group, as transmitted by the choreographer to the audience during a performance, Theatrical or Community event. The study is focused on two direction, one being the choreographer implications in the preparation of the Theatrical representation of Pontian dance Serra, and the second direction being the description of Serra dance and its potentially to provoke prosthetic memory, through commemoration practices.
\end{abstract}

Keywords: Art, Choreology, Serra Dance, Pontian ethnics, Pontian Genocide 